\title{
The Relationship between Metatext and College Stu- dents' Writing Quality
}

\author{
Chang Li \\ School of Foreign Languages, Qilu University of Technology, Jinan, China
}

\begin{abstract}
Metatext, as a recurrent topic, has long been well studied and shown to be a prominent feature of various types of academic discourse. But very few studies have paid attention to the empirical work about the effects of metatext on English writing skills of Chinese college students. This paper aims to find the relationship between the use of metatext devices as well as whether or not the quality of writing and the direct instruction of metatext markers can enhance EFL students' writing ability.
\end{abstract}

Keywords: Metatext, EFL, ESL instruction, English teaching, English writing

\section{Introduction}

Recently, metatext or metadiscourse has been studied from a descriptive point of view and has been revealed to be a prominent feature of various types of academic discourse, including university textbooks and doctoral dissertations. It has also been investigated comparatively to understand differences in usage across cultures. Some work has focused on metatext in student writing. [1] analyzed EFL (English as a Foreign Language) university students' essays and concluded that good writers can use a greater variety of metatext markers than poor writers. [2] conducted an experiment to test the effect of the targeted metatext instruction of native-speakers' writing abilities. However, very few studies have paid attention to the functions of metatext in particular context and little experimental work has been done about the effects of metatext on English compositions of Chinese college students.

The present research contributes to the study of metatext both important theoretically and practically. Theoretically, the findings of this research are expected to add to the body of knowledge of, and to contribute to the development of existing theories of metatext. More importantly, this study is one of the first in Chinese context to explore intensively the relationship between metatext teaching and writing skills. The findings of the present study may provide practical values for EFL teaching and learning in China. Since this is one of the quantitative studies in China to investigate thoroughly the development of writing capability of EFL learners, it might serve as a model or provide implications for future research of the same kind. Moreover, the findings of the study might contribute to the EFL teaching in China since they assist Chinese teachers to understand their students' knowledge of metatext better and to design reasonable syllabus that can support and improve Chinese students' language proficiency.

\section{Literature Review on the Study}

Some focus on listening, and [3] investigated the role of metatext in lecture comprehension and did research on to what extent the presence or absence of metatext affects lecture comprehension. [4] also aimed at exploring the role of metatext in listening comprehension that implies that they can perceive the presence or absence of metatext in the lecture unconciously.

Many researchers have made attempts to examine the contributions that metatext can make to language pedagogy. Traditionally, the focus of an immense part of the literature on metatext has been on reading comprehension and believe that using metatext facilitate readers to understand intertextuality and discourse texture, to infer intended meanings, to share pragmatic presuppositions, and to interpret the institutional and ideological connections behind the text. [5]described exploratory classroom research with a group of Italian university students to gain further insight into the effect of metatext on ESP reading comprehension. [6] attempted to determine the effect of explicit instruction of metatext markers on EFL learners' reading comprehension. [7]depicted an exploratory classroom research with a group of Italian college students to get further insight into the effect of metatext on ESP reading comprehension. Students in two groups read selected extracts respectively from two versions of the same material different in quantity and type of metatext. The finding implies that a more prominent use of metatext results in better comprehension.

Relatively less work has been done concerning writing. By comparing the texts written by American and Finnish university students, [7] investigated the cultural and gender variations in the use of metatext. [8]compared the overall frequencies of adverbial connectors used by Swedish, French and British university students in their composition and discovered that in contrast to many EFL learners of other language backgrounds, the Swedish learners tended to underuse conjunctions. [9] studied the differences and similarities in the use of metatext markers by Spanish- and English-speaking writers. [10] presented a contrastive analysis focusing on the differences in the use of two selected metatext categories, previews and reviews, in English and Slovene research articles. [11]took a contrastive approach and examined writer manifestation in three languages, English, French and Norwegian, and three disciplines of economics, linguistics and medicine and suggested that English and Norwegian were both representatives of writer-responsible cultures, while French represents a reader-responsible culture. These studies pro- 
vide partial evidence for the universality of metatext and reveal the features in the use of metatext from crosscultural and gender-cultural perspectives. These features show the variations in the use of metatext in cultural context.

Some researchers put their eyes one item of metatext. [12] discussed differences in academic discourse presentation involving preference for the use of first person singular form "I" in some languages vs. "we" perspective in others. Data are exhibited concerning adoption of the two perspectives in English, Russian, French and German research articles in linguistics. However, much work needs to be done about the relationship between metatext and writing on EFL backdrop.

\section{Methodology}

\subsection{Research Questions}

The purpose of this research is to gain more insight into the relationship of metatext and writing in an L2 setting. The present research aims to uncover the existence of any relationship between the knowledge of metatext markers and the EFL learners' writing ability. To this aim, the present study is motivated to answer two questions: 1 . What is the relationship between the use of metatext devices and the quality of writing? 2. Does the direct teaching of metatext markers enhance the students' writing ability? If it does, how can it enhance writing ability?

\subsection{Participants}

This study was conducted in two classes, totally 60 students from two natural classes of Qilu University of Technolgy. Each class consisted of 30 freshmen, who were Material and Chemistry majors enrolled in four-credit Intensive Reading Comprehension course as a requirement for their BS degree. They were randomly made the Control Class (CC) and the other the Experimental Class (EC). 18 males and 12 females are in the Control Class and 20 males and 10 females in the Experimental Class. The two classes were considered to be equal in language learning ability because they obtained similar scores on the pre-test, which was administered to test whether there was any difference between the two classes before the treatment.

\subsection{Data Analysis}

In this study only quantitative analysis is adopted, which comprises comparing the mean scores of the compositions written by each group, counting the tokens and types of metatext devices, computing the tokens and types of metatext devices used per one hundred words and computing the coefficient between the use of metatext per one hundred words and the writing quality. To fulfill the purpose of the experiment, Vande Kopple's (1985) system of classification was adopted.

To test if students of EC and CC have the similar English writing capacity, their pre-test scores were compared. Similar procedure was adopted with the data analysis process above and if the significance level is below 0.05 , the null hypothesis that the means of the two classes are equal is rejected, and vice versus.

To test whether the instruction of metatext has taken effect, the independent and dependent paired samples t-test was utilized by running SPSS 11.5 procedures. First, scores of pre- and post tests of CC were compared and dependent paired samples t-test was adopted. Then, similar process went with pre- and post tests of EC. Next, independent t-test was used to compare post tests of $\mathrm{CC}$ and EC. During the whole process, the mean difference is significant at the .05 level in this data analysis, which means if the significance level is below .05 , the null hypothesis that the means of the two groups are equal is rejected, and vice versus.

\section{Results and Discussion}

The results consist of the comparison of the scores of preand post tests between EC and CC and features of good and bad essays. At the same time, questions proposed before will be answered in this part.

\subsection{Results}

T-test examines how well each of the group does on the post-test and whether there is any difference between the means of the two groups after instructions on metatext. The observed t-value is -2.129 , which is significant because the observed significance level .038 is below 0.05 . Therefore the null hypothesis that the means of the two groups are equal is rejected and the results reveal a significant mean difference. The result shows that after instruction, the writing ability of EC is better than that of CC.

On the whole, no significant correlation is found between the use of textual metatext devices and the writing quality (coefficient $=-0.102, \mathrm{p}<0.127$ ); however, significantly positive but weak relationship is found between the use of interpersonal metatext devices and the writing quality $($ coefficient $=-0.226, \mathrm{p}<0.001)$.

Two reasons can explain why no correlation exists for EFL learners. One is that the textual metatext devices are adopted in a redundant way. Stylistically, the textual connectives they used were colloquial in character. The other reason might be that, in general, textual connectives do not add propositional material but facilitate readers to comprehend such material. Appropriate use of them will assist the process of reading and understanding. Inappropriate use of them will only debase the text quality and misguide readers. In the light of the two reasons, the seemingly unreasonable result came as no surprise.

One observation worthy of research is the negative yet weak relationship between the use of interpersonal metatext devices and the writing quality (coefficient $=-0.226$, $\mathrm{p}<0.001)$. This implies that the use of interpersonal metatext devices in an argumentative essay could improve the writing quality in some measure. Further analysis indicates that the use of illocutionary markers (coefficient=-0.187, $\mathrm{p}<0.008$ ) and attitudinal markers (coefficient $=-0.197$, $\mathrm{p}<0.007)$ also bears negative but rather tenuous relationship with the writing quality. It seems that the more illocutionary and attitudinal markers a composition has the lower quality it would have.

There is no significant correlation between the use of validity markers and the writing quality (coefficient=$0.125, \mathrm{p}<0.060$ ). Closer analysis, however, reveals that a negative but tenuous relationship (coefficient=-0.147, $\mathrm{p}<0.05$ ) exists between the use of modals and the writing quality. The reason might reside in that the EFL learners 
under investigation, for the most part, exhibit the tendency to overuse modal verbs such as "can", "should", "must" and so on. No significant correlation was found between the use of emphatics and hedges (coefficient $=-0.028$, $\mathrm{p}<0.574$ ) and the writing quality (coefficient $=0.055$, $\mathrm{p}<0.430)$.

\subsection{Discussion}

As presented in previous part, although the writing quality of CC did improve, the pace is not as much as that of EC. The improvement of CC could be justified as normal improvement through the traditional way of learning. The gap between the two classes could be described as the subjects' weakness in applying metatext markers in an effective manner on their own for CC. This suggests that teaching students to use metatext is a valuable way of improving their writing skills.

One reason for this phenomenon can be that the students receiving instruction on metatext are able to recognize different kinds of metatext markers, interpret the functions performed by them, and use metatext in a more appropriate way so that the framework of their texts is better organized. They will know how to put the introduction, the body or conclusion of a text; they will know what expressions to use to imply the shift of topic; they will know how to enlighten their ideas. The second justification is that teaching students to use metatext makes them more sensitive to the reader's needs and they begin to consider the text from the perspective of potential readers. The emphasis on metatext and the exploration into its effects on the reader influence them to be more reflective about what they are saying and how they are saying it. They begin to pay attention to the needs of the readers or in another words, their essays are more reader friendly.

The third point worth mentioning is that the knowledge of metatext helps the students who receive instruction on metatext in their revising process. The knowledge of metatext places them in a position to judge whether they use too much metatext to compromise their primary message, whether they do not use enough metatext and thus produce unfriendly texts or whether they use metatext inappropriately. In addition, knowing the terminology of metatext makes it easier for them not only to locate the problems but also come up with specific solutions.

\section{Conclusion}

In this part, major findings of the study are reported first. Then, weaknesses of the study are also briefed. Finally, future research dimensions inspired by the study are suggested.

The findings of the study are summarized as follows: First, A traditional model for the organisation of language lessons, both in the classroom and in course-books, has long been the PPP approach. With this model individual language items (for example, the past continuous) are presented by the teacher, then practised in the form of spoken and written exercises (often pattern drills), and then used by the learners in less controlled speaking or writing activities. However, as to the metatext instruction, direct teaching of metatext can have positive influence on students' writing ability and TBL model is proved to be an effective model to apply in classroom.

Second, there is no significant correlation between the use of textual metatext devices and validity markers and the quality of writing. No significant relationship was found between the use of validity markers and the quality of writing. A negative relationship is found between the use of attitudinal markers and the quality of writing. As to the relationship between the use of attitudinal markers and the writing quality, a negative but weak correlation is found. This result demonstrates that the quantity of metatext might not determine the quality of writing.

In spite of the deficiencies, the study contributes to the theory of metatext and provides pedagogical suggestions for the classroom English writing instruction.

\section{Reference}

[1] Intaraprawat, P. and Steffensen, M. The Use of Metadiscourse in Good and Poor ESL Essays[J]. Journal of Second Language Writing, pp. 253-272, 1995

[2] Steffensen, M., and Cheng, X. G. Metadiscourse and Text Pragmatics: How Students Write after Learning about Metadiscourse [J]. Research in the Teaching of English, 30 (2), pp. 149-181, 1996.

[3] Perez, M. and Macia, E.Metadiscourse in Lecture Comprehension: Does it Really Help Foreign Language Learners[J]. Atlantis, 14(2): pp. 3-21, 2002.

[4] Wu, S. An Empirical Study of the Role of Metadiscourse in Listening Comprehension[J]. Celea Journal, 31 (1): pp. 87-97, 2008

[5] Camiciottoli, B. Metadiscourse and EAP Reading Comprehension: An Exploratory Study [J]. Reading in a Foreign Language, 15(1): pp. 28-44, 2003.

[6] Alipour, A. J. M. How Explicit Instruction Maks a Difference: Metadiscourse Markers and EFL Learners' Reading Comprehension Skill (J) . Journal of College Reading and Learning, 38 (1): pp. 35-52, 2007.

[7] Crawford C.B. Metadiscourse and ESP reading comprehension: An exploratory study. Reading in a Foreign Language (RFL), 15(1), 2003.

[8] Crismore, A., Markkanen, R., and Steffensen, M. Metadiscourse in Persuasive Writing: A Study of Texts Written by American and Finnish University Students [J]. Written Communication, 10(1): pp. 39-71, 1993.

[9] Altenberg, B. and Tapper, M. The Use of Adverbial Connectors in Advanced Swedish Learners' Written English [A]. In Granger, S. (eds.), Learners' English on Computer [C]. London and New York: Longman, 1998.

[10]Sáez, F. Culture in Writing [M]. Published in Tadea seu liber de Amicitia, 2003.

[11]Peterlin, A. Text-organising Metatext in Research Articles: An English-Slovene Contrastive Analysis [J]. English for Specific Purposes, 24(3): pp. 307-319, 2005.

[12]Dahl, T. Textual Metadiscourse in Research Articles: A Marker of National Culture or of Academic Discipline [J]. Journal of Pragmatics, 36(10): pp. 1807-1825, 2004. 
[13]Vassileva, I. Who Am I/Who Are We in Academic Writing? A Contrastive Analysis of Authorial Presence in English, German, French, Russian, and Bulgarian [J].
International Journal of Applied Linguistics, 8(2): pp. 163-90, 1998 